\title{
13 Becoming a feminist academic in Japan and Norway: A dialogue with professors Masako Ishii- Kuntz and Agnes Bolsø
}

\author{
Jennifer Branlat, Agnes Bolsø, and \\ Masako Ishii-Kuntz
}

\section{Feminist dialogues}

The following dialogue between Masako Ishii-Kuntz, Professor Emerita and Vice Dean of Ochanomizu University (Japan), and Agnes Bolsø, Professor Emerita at the Norwegian University of Science and Technology (NTNU, Norway), began in virtual space, as did most meetings during the COVID-19 pandemic, in late 2020 and continued to June 2021. Its purpose was to explore the ways in which these two professors in Gender Studies view their professional trajectories in a wider perspective than that of the traditional career narrative. The dialogue sets into play questions of early lived experiences from childhood, the possibility or impossibility of finding a 'home' in feminism at various points in time and of pioneering academic work in the highly interdisciplinary and international field that Gender Studies is today.

A dialogical approach such as the one featured here has two principle aims. First, it opens up a space for the participants' existential 'struggles of becoming' to take form (Frank, 2005, p. 968). Rather than Profs. Ishii-Kuntz and Bolsø presenting themselves solely through categories such as 'feminist academic' or 'sociologist,' which emphasise professional identities over personal, the aim here was to show how the professional and personal are intertwined and interrogate each other. Second, dialogical enquiry allows for stories to emerge in a shared space - in this case a virtual one - and during moments of contact with others. Finally, the dialogical welcomes the influence that all speakers have on each other's storytelling processes.

Both born at the beginning of the 1950s into quite non-traditional families during the 'housewife era' of the post-war period, Masako IshiiKuntz and Agnes Bolsø embarked on journeys, which, although geographically distinct, resonate in many respects. Professor Ishii-Kuntz grew up in the small fishing town of Rumoi, Hokkaido, the most northern island of Japan. She pursued her undergraduate and graduate studies in Family 
Sociology in the US. After 20 years at the University of CaliforniaRiverside, she returned to Japan with the strong desire to work with the motivated young women at Ochanomizu University, where she led the Institute for Gender Studies from 2015 to 2020 and is now Trustee, Vice President and Professor (Emeritus). Her research concerns gender dynamics both in families and in the workplace, with a particular focus on Japanese fathers' involvement in housework and childcare. A major part of her Japanese fatherhood research has stemmed from her involvement in an advocacy group for shared parenting, which was the driving force for the 1992 law giving men the right to take family leave from work. Her research on the 'Ikumen' phenomenon - 'cool' fathers who are actively involved in caring for their own children - has been instrumental in establishing a space for men and masculinity in the field of Gender Studies.

Prof. Bolsø grew up on a coastal farm in Ørland, Norway, as the daughter of a wartime sailor and midwife. She has been head of the Centre for Gender Studies at NTNU, editor of The Norwegian Journal of Gender Studies and involved in the development of Norwegian feminism, Women's Studies and Gender Studies since the 1980s. After beginning her university studies in mathematics, she was quickly politicised in the 1970s and went on to study Sociology and History. She obtained practical training as a researcher in agricultural and rural studies before specialising in Gender Studies. She has generated a thematically broad academic output on gender, sexuality, and power and politics. Prof. Bolsø is currently pursuing research on trans bodies and femininity, enquiring into the role of symbolic gender in trans transformations.

The dialogue between Agnes Bolsø and Masako Ishii-Kuntz was mediated and edited by Jennifer Branlat, whose questions appear as headlines throughout the dialogue. Jennifer is a post-doctoral researcher and feminist educator at the Norwegian University of Science and Technology.

\section{How did you arrive at where you are today?}

\section{AGNES BOLSØ:}

In terms of career, I would say it was random. First, I had planned on becoming a math teacher and then politics erupted onto the scene in the 1970s, and I realised I couldn't save the world with mathematics. I changed to History and Sociology. As a student in Sociology, I had a teacher who belonged to the same political movement as me and hired assistants to do data processing on punch cards. I was coding for him, but I also really enjoyed his teaching. As a result, I ended up moving into his field of research, 
which was Rural Sociology. I did both my Bachelor's thesis and my Master's thesis with him as a supervisor. I think I was still planning to become a teacher when politics took hold of me during my Master's. I proletarianised myself and that's how I came into research. I was still working in agriculture and five months pregnant with my son when I was recruited as a researcher for the Center for Rural Research. I was always a feminist, socialist, communist and supporter of green politics from the 1970s onward. It was a whole package. A very exciting journey.

It was difficult to get funding for sexuality research at the Center for Rural Research, so I jumped to Gender Studies, and that was where what you could call a 'career' started. That was also accidental. I got a Ph.D. and filled in as a professor until I obtained a permanent post. I think I was much less strategic than I was just taken by the events.

\section{MASAKO ISHII-KUNTZ:}

In my case, I grew up in a family where my mom didn't really do much in terms of childcare or housework. It was my father who performed all the domestic tasks. As a result, I grew up questioning why that was the case, because in my friends' families it was their mothers who were taking care of them. In Japan (at least in my childhood days), children bring bento lunches from home, and it was the case that my lunch never seemed to look as attractive as those of the other girls, whose bentos were made by their mothers. I grew up thinking that something must be wrong with me or my family. By the time I graduated from high school, I imagined that my college education should take place somewhere outside of Japan because I knew that I wouldn't be able to find the answers in Japan. I left Japan in the early 1970s and started my college education in the US, in the wake of the 1960s civil rights movement.

After my undergraduate degree, my parents said that I had reached the end of their financial assistance, so I had to get a job but didn't have a work visa in the US. I had to come back to Japan. I began working for an English language newspaper, and it was then that I was exposed to gender discrimination that existed in Japanese working life. At the time, I didn't want this to be my future, so I worked, saved money and was able to go back to the US after four years of working. I remember thinking that English language newspapers would be liberal, but my experiences ended up being quite the opposite. After four years, I 


\section{Jennifer Branlat et al.}

entered my Master's program, and after my Ph.D. I decided to stay in the US because of my experiences with discrimination at the newspaper company. At the time, I didn't want to come back to Japan at all. I ended up getting a job in the Sociology Department at the University of California, Riverside [UCR]. 'Pressure cooker' would be the words to describe my years at UCR because of the 'publish or perish' research environment. I survived this battle to receive a tenure in 2003, but I began to feel that something was missing in my career, namely teaching for the future generations. Throughout my career in the US, I maintained a part-time teaching post at Ochanomizu University, one of the two national universities in Japan for women. For several summers I would teach a graduate seminar, and I came to be quite fascinated by the quality of the female students in terms of their seriousness towards learning and their high level of motivation. I felt like my mission in life was to return to Japan to work with these brilliant students and contribute to their future development. The fact that I am in Japan now and have been for the last 15 years was something that I didn't plan on. [laughs] You just never know.

\section{AGNES BOLSØ:}

It seems that both of us were embarrassed about things we are quite proud of today. Your story about your norm-breaking parents reminds me of my mother. I feel a deep solidarity with the women that came before me: My free-spirited aunt but also my mother, who was more grounded. She was a nurse during the war and helped evacuate patients by boat from the local hospital to the islands during the German bombing of Kristiansund in 1939. It was in this context that she helped a woman give birth in fairly dire circumstances. This event affected her, and she ended up going to a midwife school in Oslo. She worked as a midwife during the rest of the war. My mother was tough.

My father was a convoy sailor during the war and like so many men, under the constant threat of torpedo strike, he had a breakdown and had to be hospitalised. He ended up falling in love with a nurse in the hospital, and when my mother happened to find one of their love letters, she put on her coat and left for Trondheim to seek legal help. My father told her she couldn't obtain a divorce since they had children, but the lawyer told her differently. She raised us alone. She was a feminist, but she probably never said the word in her life. She divorced my father in 1953, the year I was born. No one we knew was divorced in 1953. The one memory - even though there are so many - I have of my mother 
being different from other mothers was when we went to church. She wasn't a Christian, but there was no entertainment in the village of 300 people so she went to church to listen to the organ and the singing. She loved to sing, and she knew all the words. She would sit straight up - she was quite tall - and she sang the absolute loudest of the congregation. Always. At the time I was ashamed but now, thinking about it, I'm so proud. Then later when she took a position in a more remote area, she bought herself a moped, a helmet and big gloves [laughs].

\section{How are the words 'feminism' and 'gender' used in Japan?}

\section{MASAKO ISHII-KUNTZ:}

Beginning in the late 1990s and early 2000s, there was a period of five or six years of the so-called 'gender bashing' or 'gender-free bashing' in Japan. Anything and everything related to gender came under scrutiny. I was, in fact, advised not to use the word 'gender' when I was invited to give a talk. I was quite offended, as you can imagine. In many cases, the words 'feminist' and 'feminism' have been reserved for academics to a great extent. The terms have not been used on the same level among the general public. Perhaps that's why we do encounter criticisms here and there levelled against feminist philosophers or thinkers in academic sense, but we don't hear muchelmets' who organised a series of demonstrations, the most well-known of which involved storming into the Diet, the National Assembly, wearing pink helmets. Those sorts of women represent the very active or radical women who are opposed to the government, which at the time opposed the idea of birth control pills. In those days, though, we were not using the word 'feminism' at all to describe these women. Rather, the words 'Women's Lib (Liberation) Movement' were used to describe female activists in those years. So, in a sense, these women were known as activists for women's causes, not feminists per se.

\section{What about the term feminism in Norway?}

\section{AGNES BOLSØ:}

Today feminism in Norway can be anything. There are all sorts of feminisms. I think we could just be pragmatic about the word 'feminism' and let it reflect the context: the relevant cause/topic and 


\section{Jennifer Branlat et al.}

those who are involved, where and when. Sometimes it is women's issues, sometimes it's gender issues and sometimes sexuality or feminism itself that's at stake. The choice of word depends on the concrete context. All the words are contestable, and it's quite difficult to find a word that is uncontested. I became a feminist, a conscious feminist anyhow, in the early 1970s. I belonged to the communist/socialist student left at the time, and feminism to me was a bourgeois word used among the liberal right. This was not altogether true, as I see it in hindsight! But to me it had roots in the suffrage movement, which was primarily a bourgeois, upper-class political movement. Feminism first arrived with the French Revolution and was connected to the acquisition of civil rights. When the leftist women's movement came along in the 1970s, it was for me all about liberation - women's liberation but also everybody's liberation from the capitalist system within which the bourgeois feminist had secured her rights.

\section{How about feminism and class in Japan?}

\section{MASAKO ISHII-KUNTZ:}

I think that's quite similar within the Japanese context in which highly educated, well-to-do middle- to upper-class women were very active in pursuing their ideals or expressing their opinions with respect to the use of birth control pills.

\section{Feminism today - is it still about class?}

\section{AGNES BOLSØ:}

Throughout history, if you look again at the suffrage movement, the upper-class women who participated were labelled feminists and really had a hard time of it. Feminism was a derogatory label. They were not seen as proper women - they were called men in skirts, sometimes hardly considered humans since they were understood as neither 'man' nor 'woman.' There's an echo of it in today's boardroom feminism, or Gucci feminism as it is sometimes called. Corporate feminists don't want to use the words 'feminism,' or 'women's liberation' because they are first and foremost meritocrats. It's all about competence and qualifications and the right to have a position based on competitive processes. If today's feminism is a very broad term, 
it encompasses all sorts of ideas about women and society, and the relationship between men and women and capitalism. It lends itself to different kinds of analysis. That's why I say we have to be pragmatic feminism cannot mean one thing. When we say feminism, it could literally mean anything that has to do with equality, where women and men are involved. I would say, though, that the echo of the derogatory is still very much in place.

\section{MASAKO ISHII-KUNTZ:}

I think, in case of Japan, the word 'feminism' or even 'gender,' or 'femininity' and 'masculinity' - all of these have been used by bourgeois women, but at the same time by men who are against anything to do with women. Politicians, male politicians, or those espousing dominant culture have used, for example, gender in the gender-bashing context and feminism the same way. In that sense, there are different kinds of feminism that exist in Japan, too. But as far as being the target of criticism, all feminisms have become the target of both politicians and upper-class men.

\section{What was your experience of attending university during the tumultuous 1970s?}

\section{AGNES BOLSØ:}

During this period in Norway, it was a time of fagkritikk or, to put it in English, critiquing the disciplines. There was nothing - and I mean nothing - about women's issues on the reading lists. In History and Sociology, we created our own courses, seminars and reading lists [shows the papers from her personal archive]. In History, for example, we made a course on women in working life and the Norwegian women's movement. We actually received university credits for this course, which was established with the help of a socialist professor in the History Department who helped obtain official recognition. There was another from Sociology called 'women and production' that discussed women as the reserve army under capitalism and women's relationship with the trade unions. We created it and we also did the teaching as undergraduate students [laughs]. There was a critique in every discipline that not only women were invisible, but the working class was invisible, and rural people were invisible. It was the white upper-class man that was visible in every discipline. This effort to make women and women's situational historical contexts visible was deeply empirical. 


\section{MASAKO ISHII-KUNTZ:}

I have to admit that you were ahead of me in the 1970s in your undergraduate studies. When I was an undergrad at an American college in the 1970s, the American women's rights movement was in full swing from the 1960s. A couple decades later, we read a book that I remember quite well, Carol Gilligan's In a Different Voice [1982]. This book acted as an eye-opener for me because it helped me better understand the ethics of care and how it is internalised by women. In understanding my own family, especially my father's involvement in childcare, I thought Gilligan's views could also be adopted by men who care. Gilligan was occasionally criticised for not providing data to support her arguments, but even if I were to read her work for the first time now, I would still learn a great deal about the ethics related to domestic care work. In my college days, we were just given the readings and were asked to read them. Through the readings we came to discover many dimensions of women's issues, but we didn't create courses or reading lists like Agnes did [laughs].

\section{Was feminism part of your motivation to build a career in the academy?}

\section{AGNES BOLSØ:}

For me, it was all about women and women's liberation, increasing women's strength in all areas of society. I wasn't using the word 'feminism' at the beginning. I started out as an applied researcher in Agricultural and Rural Sociology funded by the government and by agricultural corporations and organisations. There was a lot of work to do to give rural women confidence and in bringing feminist points of view into all sorts of research topics. We women did not obtain the right to inherit a farm until 1978, which was quite late. Prior to that, family farms were passed to the son, which means it took quite a while to change attitudes and get boys and girls to be treated equally in agriculture. My research was related to a deep gender division in agriculture, and I saw it as my task to work to strengthen women's position in rural areas. 'Feminism' as a concept was not a part of that picture. It was about women's confidence and rights. 


\section{MASAKO ISHII-KUNTZ:}

As I said, I grew up thinking that there was something wrong with my family because of my father's heavy involvement in housework and childcare. I didn't even know the word 'feminism' then, of course. But looking back, I definitely became fascinated by feminists' writings in pursuit of my childhood questions. So, yes, feminism was part of my motivation in building my career as a sociologist. When I began to do research on housework and childcare during graduate school in the 1980s in the US, I was told by many male professors that there wasn't much to research in the division of household labour. They claimed the topics of housework and childcare were too 'domestic,' that they were 'women's issues' and that it was important to set my sights higher. I remember being warned by American male professors that conducting research on housework and childcare was most certainly not the overarching research theme that I should be pursuing. But given my childhood experiences and being strongly influenced by feminists' thinkers, I remember feeling that I must find the answers to explain the phenomenon of gendered division of household labour.

\section{Which aspects of women's situation did you try to make visible in your research?}

\section{MASAKO ISHII-KUNTZ:}

In the 1980s when I was interviewing women who were trying to build certain careers, I heard them saying over and over, 'I have to be a man to succeed.' It was quite commonplace, you know, that their partners were not helping them at all at home. Interestingly, it was their mothers who were helping them to raise their kids or with whatever household tasks that needed to be completed. Those career women were forced to be the front runner: Embodying a form of masculinity, the ability to compete or showing off that they could do just as much or even better than men. In many respects they had to present themselves as men. It's also not as common in Japan to seek domestic help. I think there is a strict line between what's considered public and private. Many Japanese 
people believe that family falls completely within private domain and therefore don't wish to bring outsiders into their private space. That leaves restricted possibilities for who can help with children and housework. That's why these domestic tasks fall on the mother. Given these domestic responsibilities that have been falling on women, I felt what I could do through my research was to discover the 'caring' aspects of fathers. I believed that mothers' experiences of childcare stress and anxiety can be alleviated through their partners' involvement in domestic tasks. Thus, in my research, I have identified both work- and family-related factors affecting men's involvement in childcare and housework. I have also examined how men's housework and childcare would influence women's psychological well-being. Most recently, I have been involved in a research project that examines 'caring masculinity,' which rejects men's domination and its associated traits and embraces values of men's care as positive emotion and relationality. Thus, you can say that my feminist approach has been not only for the benefits of women but for those of men as well.

\section{AGNES BOLSØ:}

I think I touched on my commitment to bringing women's voices into research in what we tried to accomplish at the Center for Rural Research. After that, there was a theoretical change, and sexuality came to the forefront with two big research programs through The Research Council of Norway - I had funding for both of them. They were called Gender in change [Kjønn $i$ endring] (1996-2001) and Gender Studies: Knowledge, limits, change [Kjønnsforskning: Kunnskap, grenser, endring] (2001-2008). It wasn't so much women's situation I was interested in but rather the ways in which sexuality, eroticism and the symbolic aspects of gender are deeply coded into culture. The symbolic aspects of gender are things that men and women, whether straight or queer anyone can play around with them. They reveal that masculinity doesn't have to be attached to men. Around this time, the notion of 'women's situation' became old-fashioned sounding, particularly in the context of the welfare state with its benefits for both men and women via parental sharing and the dual-earner model. The welfare state made women essential to the family economy and has facilitated male parenting. It's no longer a question of women's situation. 


\section{Feminist theory - inspirational or instrumental?}

\section{AGNES BOLSØ:}

It was with Judith Butler that I started to be interested in theory. Feminist theory of course existed before Judith Butler, but as an applied researcher, I wasn't able to relate so much to feminist theory. I knew about it and was familiar with the ideas and discussed them, but in applied rural research it was women, men and women's rights and increased confidence for women that we were interested in. That was when I made a point of the fact that women who said they didn't drive the tractor actually did drive the tractor. They had to do it for practical reasons rather frequently, and so they did it. I realised that they actively took part in portraying their role and importance as less than it was in reality. Women taking part in their own diminished positioning started to puzzle me more and more, and I needed more fine-grain tools and foundations for thinking about gender, and women and men, so feminist theory provided a way in. By this time, men's studies had come along, and in combination with Butler's deconstructing of man and woman altogether - that was really something. Something new and very compelling. But I think perhaps the most significant realisation for me came with a shift in my own sexual desires. Until my thirties, I had been straight, had children with a man that I loved and truly desired men. Falling in love with a woman and starting to desire women was quite puzzling and challenged me in ways that I wanted to study. I began to study this experience by reading about sexuality and the erotic, but also by doing my own project on my body. It was like going through puberty again. That was when I left rural studies. I suppose everything was driven by my own development. In any case, it wasn't possible at that time to obtain funding for projects on rurality and homosexuality. That's when I left rural studies and joined the group that had by then been formed at the university, the Center for Women's Research. It was both accidental and driven by my own desires.

It wasn't until the 1990s in the wake of Judith Butler's Gender Trouble [1990] that it really hit me that my theoretical understanding of 'man' and 'woman' meant something also for my academic research, and that there were already feminist theoreticians worth reading and listening to out there. You know, Aleksandra Kollontai and Rosa Luxemburg can only help us with some things and not others! It's quite embarrassing to admit this 
today, particularly when Gender Studies has become institutionalised and theory now occupies a central space.

\section{MASAKO ISHII-KUNTZ:}

It's fascinating to hear your reflections because there are so many overlaps. We were born and grew up in totally different cultures. Yet, I was also quite influenced by Judith Butler myself. During my undergraduate years, we also had to read Betty Friedan's Feminine Mystique [1963], and other pillars of feminism and feminist thought. In my readings of those texts, I really felt like, 'aha!,' this is the answer I've been searching for in relation to my family being different from others. It was an eye-opening experience for me, not just going to the US but reading some of the early feminist intellectuals' theoretical writings. Then, with Judith Butler, I was very taken with the concepts of deconstruction and performativity. I was also fascinated with the theoretical frameworks of R.W. Connell about masculinity. The concept of diverse masculinities rather than 'the masculinity' which has been presented in contrast with 'femininity' was especially inspirational in my pursuit of fatherhood research.

I find many similarities between Agnes' and my own experiences as undergraduates and then as Master's students. In particular, I also started out first and foremost as an empirical researcher. I read feminist writings, but not with the intent to use theories from those readings, but more or less as inspirational readings and guides. I was conducting empirical research as a family sociologist with a focus on gender inequality in families. I eventually came to realise the importance of theoretical thinking with respect to feminism and gender issues, but I definitely started out as an empirical researcher. In that sense, our backgrounds are quite similar. I remember reading interdisciplinary works - feminist perspectives on women - and I read those books without thinking too much. But I eventually came to think that I could apply theoretical dimensions to my empirical research. I was initially reading them for inspiration.

AGNES BOLSØ:

Empirically-grounded research, with few exceptions, was the founding principle for the Center for Women's Research in Trondheim, which was created to connect all these influences from different disciplines that had been raging throughout the 1970s and 
the 1980s in history, psychology, mathematics, biology - everywhere. The idea was that all these researchers from different empirical fields and disciplines would have a place to connect. Initially, we didn't teach our own courses; we coordinated the attempt to make women and the distinctions between women and men in the disciplines visible, as a consciousness-raising in a way. In the 1990s when Women's Studies became Gender Studies and 'feminist theory' was really established as a concept and a tradition, theory became central in the introductory classes to what now had become a field in its own right.

\section{What was the answer to your burning question about why your family was different?}

\section{MASAKO ISHII-KUNTZ:}

[laughs] There are many, many answers. Actually, my main discovery was that there was more than one answer for my question. But one of the eye-opening answers that I learned in Sociology courses in the US was that my dad probably lacked the resources to compete with my mom in terms of his social status, income and education level. He had an education to be sure, but my mother was so much more career-driven that she was too busy to pay attention to the children. My father on the other hand didn't really care about his career. He seemed to care more about keeping a diary of my milestones as a baby, what foods I ate and the things I enjoyed. I think my father cared more about his kids and less about his career.

\section{AGNES BOLSØ:}

Did you ever find out how it was possible for your father to be a norm breaker during the post-war period in Japan? I think it's an interesting topic for further research.

\section{MASAKO ISHII-KUNTZ:}

Perhaps he also didn't pay much attention about what a 'masculine' man should be or should not be doing. I remember asking him why he spends so much time with us and his answer was always 'because 


\section{Jennifer Branlat et al.}

I love you kids more than anything.' The fact that he was breaking the masculine norm of being a breadwinner at the time can be explained by his own childhood in which he often resented the fact that his own father was a very strong patriarchal presence in the family and thus was never involved in the care of his children (and there were seven of them!). This is also consistent with the complementarity socialisation hypothesis which suggests that if you grew up with a distant father, then you are more likely to be opposite by actively engaging in childcare. Now as I look back, his experiences can also be well explained by the caring masculinity concept.

Returning to my time at the university, and to the oppositions of my mentors during graduate school, I decided to pursue my research on the division of household labour in spite of the advice I received. I studied motherhood and fatherhood, family life, housework and childcare while at the same time reading feminists' theories. As a result, I not only have found answers for my own questions, but also became convinced that the research on domestic labour is more than just a women's issue. Consequently, I have been taking both gender and feminism seriously in order to further my research in this area.

\section{References}

Butler, J. (1990). Gender trouble: Feminism and the subversion of identity. Routledge.

Frank, A.W. (2005). What is dialogical research, and why should we do it? Qualitative Health Research, 15(7), 964-974.

Friedan, B., \& Friedman-Feminist Press Collection. (1963). The feminine mystique. Dell Pub. Co.

Gilligan, C. (1982). In a different voice: Psychological theory and women's development. Harvard University Press.

\section{Further Reading}

Bolsø, A. (2007). Approaches to penetration: Theoretical difference in practice. Sexualities, 10(5), 559-581.

Bolsø, A. (2010). Folk flest er skeive: Queer teori og politik [Most people are queer: Queer theory and politics]. Manifest.

Bolsø, A. (2012). Sociological discipline and the unruly erotic. Review of European Studies, 4(1), 94-106.

Bolsø, A. (2019). Kroppen og fantasiene om den. Det allmenne ved transkjønn [Bodies and associated fantasies]. Tidsskrift for kjønnsforskning, 43(4), 259-272.

Connell, R. (1987). Gender and power: Society, the person, and sexual politics. Stanford University Press. 
Connell, R. (2021). Masculinities. Routledge.

Ishii-Kuntz, M. (2009). Working-class fatherhood and masculinities in contemporary Japan. In S. Lloyd, A. Few, \& A. Katherine (Eds.), Handbook of feminist family studies (pp. 192-204). Sage.

Ishii-Kuntz, M. (2013). Sociology of child caring men. Minerva Publications.

Ishii-Kuntz, M., \& Lee, G.R. (1987). Status of the elderly: An extension of the theory. Journal of Marriage and the Family, 49(2), 413-420.

Kollontai, A., Dazhina, I.M., Mukhamedzhanov, M., \& Tsivlina, R.Y. (1984). Selected articles and speeches. Progress Publishers.

Luxembourg, R., \& Bukharin, N.I. (1972). Imperialism and the accumulation of capital. Penguin. 